\title{
Nutritional evaluation of sweet orange citrus sinensis seed oil
}

\begin{abstract}
Highlighting the nutritional benefit of oil gleaned from the seed of sweet orange Citrus sinensis has become necessary; owing to the fact that the seed is predominantly considered a waste. Therefore, the aim of the present study was to investigate the nutritional benefits of oil extracted from the seed of sweet orange Citrus sinensis of the family; Rutaceae, and order; Sapindales. A total of $2.0 \mathrm{~kg}$ of coarsely crushed seeds were immersed in 15 liters of $\mathrm{n}$-hexane for 72 hours in batches with intermittent vigorous shaking and the oil was further extracted using a soxhlet extractor. Other procedures for analysis were performed using standard methods. The result revealed that, the anti-nutrients levels were found to be within the safe limit, vitamin and minerals fell within the daily recommended intake limit. The proximate composition of Citrus sinensis seeds oil revealed that the oil contains; Protein $1.560 \pm 0.120$, Moisture content $4.636 \pm 0.153$, Fat $89.810 \pm 0.282$, Ash content $1.776 \pm 0.161$, Crude fibre $0.619 \pm 0.052$ and Carbohydrate $1.614 \pm 0.036$. Gas Chromatography-Mass Spectrometry (GC-MS) analysis revealed the presence of the following fatty acid compounds; Linoleic acid $37.644 \%$, Palmitic acid $28.051 \%$, Isopropyl linoleate $12.699 \%$, Pentadecanoic acid $9.652 \%$, Stearic acid $5.839 \%$, Butyl linoleate 2.867, and Glutaric acid $2.616 \%$. Therefore, indicating that, the oil extracted from sweet orange Citrus sinensis seeds it's an excellent choice for both nutritional and industrial purposes.
\end{abstract}

Keywords: citrus sinensis oil, proximate composition, anti-nutrients, GC-MS, sweet orange
Volume 6 Issue I - 202 I

\author{
Nwozo Sarah O, Omotayo Opeoluwa O, \\ Nwawuba Stanley U \\ Nutritional and Industrial Research Laboratories, Department \\ of Biochemistry, Faculty of Basic Medical Science, College of \\ Medicine, University of Ibadan, Nigeria
}

Correspondence: Nwozo Sarah O, Nutritional and Industrial Research Laboratories, Department of Biochemistry, Faculty of Basic Medical Science, College of Medicine, University of Ibadan, Ibadan, Oyo State, Nigeria, 200005, Tel +234-9038098I55, Emailsonwozo@yahoo.com

Received: January 17, 2021 | Published: February 12, 2021

\section{Introduction}

Sweet orange is scientifically known as Citrus sinensis (family Rutaceae), and (order Sapindales), it's a fruit-bearing plant that provides edible fruits throughout the tropical areas, subtropical areas, and it is considered an important fruit globally., ${ }^{1,2}$ Theoretically, it is reported to have originated from Southeast Asia where it was cultivated for many years, ${ }^{1}$ however, it is presently found growing around the world. ${ }^{3}$ Sweet orange Citrus sinensis appears similar to its closely related species including sour orange, Citrus reticulate, citrus Aurantium, and mandarin orange, although distinguishable by its small evergreen tree $7.5 \mathrm{~m}$ high and sometimes as high as $15 \mathrm{~m} .{ }^{3}$ It has a total global production of about 120 million tons, so it is considered one of the most important and widely grown fruit crops. ${ }^{4,5}$ The area planted to citrus in the world is approximately 7.62 million hectares. ${ }^{5,6,4}$ Correspondingly, the citrus industry, has demonstrated a great growth potential, being one of the most competitive agricultural sectors among the countries with a tropical and subtropical climate. ${ }^{5}$

Sweet orange (Citrus sinensis) is extensively processed by the manufacturing industry in order to obtain natural juices, pulps, and candies, and these extracts have been demonstrated to be a vital dietary sources of vitamin C, liminoids, synephrine, hesperidin, polyphenols, pectins, calcium, potassium, thiamine, niacin, and magnesium..$^{7,1,3}$ However, wastes generated by the processing of orange represent approximately $50 \%$ of the fruits, ${ }^{7}$ either generated by the industries or the consumer, who disposes off the seeds after sucking the juice. The existing situation can be attributed to a lack of information as to the benefits of the seed. In Nigeria, about 930,000 tons of citrus fruits are produced annually from an estimated 3 million hectares of land. ${ }^{8}$ However, about $30-50 \%$ of these citrus fruits get spoilt on the way before getting to the final consumers in the urban centers. Thus, considered a waste and consequently having an environmental impact. $^{8}$
With the intention of adding value to those wastes, minimizing environmental impacts and providing an excellent nutritional option. The use of these sub-products has become essential, since the present great potential for application in the food, pharmaceutical, and cosmetic industries. ${ }^{79}$ The oils extracted from the seeds of sweet orange $C$. sinensis have been reported to possess a different type of activities ranging from been highly effective as an antifungal agent against L. sajor-caju, which causes white rot in wood, ${ }^{10}$ can be used as specialty oils in diet, since they contain considerable amounts of bioactive compounds and antioxidants. ${ }^{7}$ Considering the waste generated from orange, the present study therefore, sought to highlight the beneficial and nutritional property of oil extracted from the seed of sweet orange Citrus Sinensis.

\section{Materials and methods}

\section{Sample collection and preparation}

Fresh sweet oranges Citrus Sinensis were purchased from an orange orchard at Fiditi, Oyo State, Nigeria and identified at Botany Department, University of Ibadan. The juice was extracted by hand pressing and the seeds were separated, washed and air-dried at room temperature in the Nutrition and Industrial Biochemistry Laboratory University of Ibadan.

\section{Oil extraction}

The oil from the seeds of Citrus sinensis was extracted using the batch solvent extraction method. The seeds were washed, airdried and crushed. A total of $2.0 \mathrm{~kg}$ of coarsely crushed seeds were immersed in 15 liters of $\mathrm{n}$-hexane for $72 \mathrm{~h}$ in batches with intermittent vigorous shaking. At the end of the $72 \mathrm{~h}$, the organic solvent and the aqueous phase were allowed to separate by gravity. The organic solvent was then decanted and the concentration of lipids in the solvent was determined. This was done by evaporating the solvent 
using simple vacuum distillations, to exclude any contamination from the solvent of extraction. The obtained oil was stored in dark bottle in the refrigerator for subsequent analysis as described by. ${ }^{11}$

\section{Determination of anti-nutrients composition of citrus sinensis seed oil}

Phytate content determination: Phytate content determination was carried out as described by. ${ }^{12}$ One gram (1g) of the test sample was weighed out into a $500 \mathrm{ml}$ flat bottom flask. The flask with the sample was placed in a shaker and extraction was done with $100 \mathrm{ml}$ of $24 \%$ Hydrochloric acid $(\mathrm{HCl})$ for one hour at room temperature. The solution was decanted and filtered. Five milliliters $(5 \mathrm{ml})$ of the filtrate was pipetted out and diluted to $25 \mathrm{ml}$ with distilled water. Fifteen milliliters $(15 \mathrm{ml})$ of sodium chloride was added to $10 \mathrm{ml}$ of the diluted sample. The absorbance reading of the solution was taken at $520 \mathrm{~nm}$.

$$
\text { Concentration }=\frac{\text { Absorbance of sample }}{\text { Gradient Factor }} \times \mathrm{DF}
$$

Where: DF=Dilution Factor

Gradient Factor=Slope of the standard curve (Figure 1)

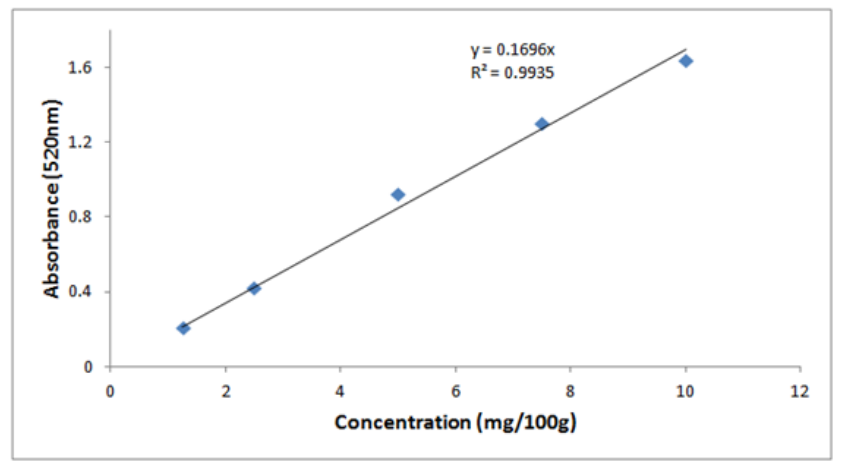

Figure I Standard curve of phytate concentrations.

Oxalate content determination: Oxalate content determination was carried out as described by. ${ }^{12}$ Two grams $(2 \mathrm{~g})$ of the sample was weighed into a $300 \mathrm{ml}$ flask. Twenty milliliters $(20 \mathrm{ml})$ of $30 \%$ hydrochloric acid $(\mathrm{HCl})$ was added to the sample and allowed to stand for twenty minutes. Forty grams of ammonium sulfate was also added and allowed to stand for another thirty minutes. The solution was filtered (with Whatman's No 1 filter paper) into a $250 \mathrm{ml}$ volumetric flask and made up to the mark with $30 \% \mathrm{HCl}$. Ten milliliters $(10 \mathrm{ml})$ of the filtrate was transferred into $100 \mathrm{ml}$ centrifuge tube. Thirty milliliters $(30 \mathrm{ml})$ of diethyl ether was added to it. The $\mathrm{pH}$ was adjusted to $\mathrm{pH} 7$ with ammonium hydroxide. The solution was centrifuged at $10,000 \mathrm{~g}$ for fifteen minutes. It was decanted into a $250 \mathrm{ml}$ conical flask and then titrated with $0.1 \mathrm{M}$ potassium tetraoxomanganate (IV) $\left(\mathrm{KMnO}_{4}\right)$. The volume used was noted.

The percentage oxalate was calculated thus:

$$
\% \text { oxalate }=\frac{\text { titrexmol } \mathrm{KMnO}_{4} \times \mathrm{DF}(12.5) \times 100}{\text { Weight of sample }}
$$

Where: DF is the dilution factor

Determination of tannin content: Tannin content determination was carried out as described by. ${ }^{12}$ One gram of the sample was macerated with $50 \mathrm{ml}$ methanol. It was filtered with Whatman's No 1 filter paper. Five milliliters $(5 \mathrm{ml})$ of the filtrate was pipette out and $0.3 \mathrm{ml}$ of $0.1 \mathrm{~N}$ ferric chloride in $0.1 \mathrm{~N}$ hydrochloric acid $(\mathrm{HCl})$ was added to it. Zero- point three milliliter $(0.3 \mathrm{ml})$ of $0.0008 \mathrm{M}$ potassium ferricyanide was also added. The absorbance of the resulting solution was read at $720 \mathrm{~nm}$. Concentration of tannin was thus calculated:

$$
\text { Concentration }=\frac{\text { Absorbance of sample } \mathrm{x} \text { DF }}{\text { Gradient Factor }}
$$

Where: DF=Dilution Factor

Gradient Factor=Slope of the standard curve (Figure 2)

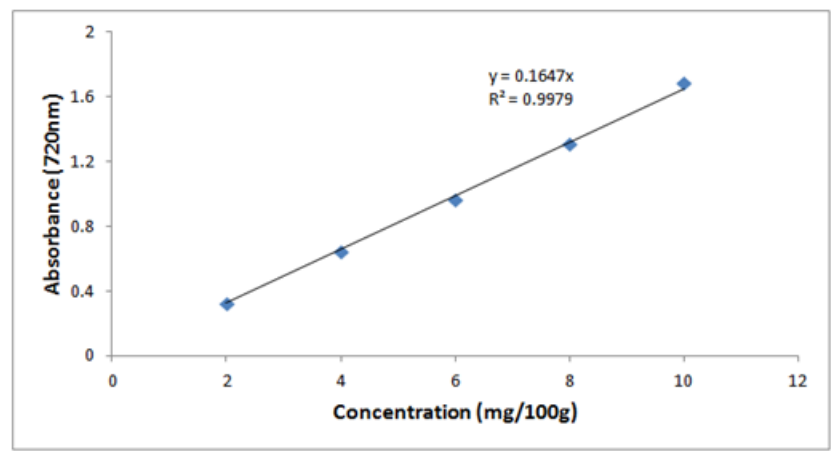

Figure 2 Standard curve of tannin concentrations.

Determination of alkaloid content: Alkaloid content determination was carried out as described by. ${ }^{12}$ One gram of the sample was macerated with $20 \mathrm{ml}$ of ethanol. A twenty percent $(20 \%)$ solution of sulphuric acid was added to the mixture in the ratio of 1:1. It was allowed to stay for $5 \mathrm{~min}$. The mixture was filtered with a Whatman's No 1 filter paper. One milliliter $(1 \mathrm{ml})$ of the filtrate was pipette out and $5 \mathrm{ml}$ of $60 \% \mathrm{H} 2 \mathrm{SO} 4$ added. They were mixed together and allowed to stand for 3 hours. The absorbance of the resulting solution was taken at $565 \mathrm{~nm}$.

$$
\text { Concentration }=\frac{\text { Absorbance of sample } \mathrm{x} \text { DF }}{\text { Gradient Factor }}
$$

\section{Where: $\mathrm{DF}=$ Dilution Factor}

Gradient Factor=Slope of the standard curve (Figure 3)

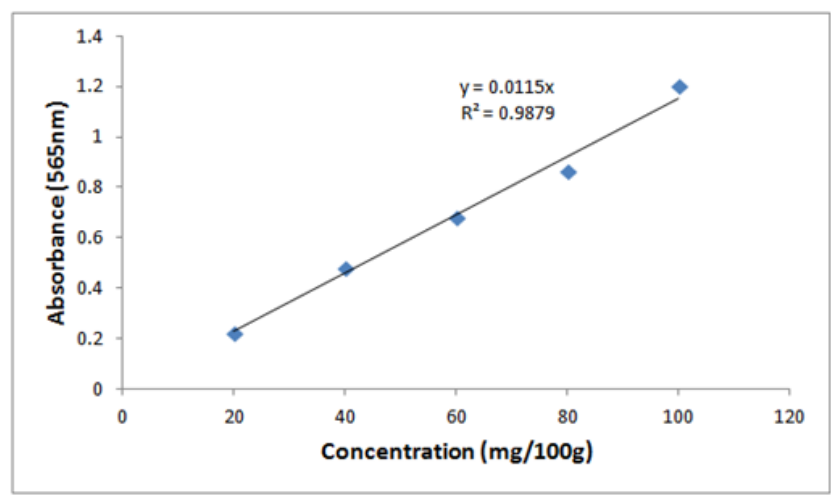

Figure 3 Standard curve of alkaloid concentrations.

Determination of saponin content: Saponin content determination was carried out as described by. ${ }^{13}$ One gram of the sample was macerated with $10 \mathrm{ml}$ of petroleum ether. It was decanted into a beaker. Another $10 \mathrm{ml}$ of petroleum ether was added to the same sample and again, it was decanted into a beaker. The filtrates from the two decantation were combined and evaporated to dryness. The residue was dissolved with $6 \mathrm{ml}$ of ethanol. Two milliliters $(2 \mathrm{ml})$ of 
the resulting solution (mixture) was transferred (or pipette) into a test tube. A color reagent (chromogen) was added. The solution was allowed to stand for $30 \mathrm{~min}$. The absorbance of the solution was read at $550 \mathrm{~nm}$.

$$
\text { Concentration }=\frac{\text { Absorbance of sample } \mathrm{x} \text { DF }}{\text { Gradient Factor }}
$$

Where DF=Dilution Factor

Gradient factor=Slope of the standard curve (Figure 4)

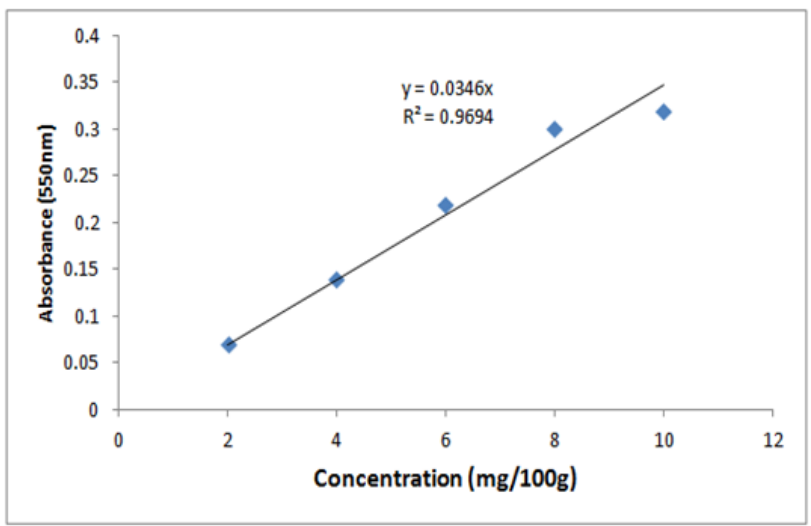

Figure 4 Standard curve of saponin concentrations.

\section{Proximate analysis}

The proximate analysis of sweet orange Citrus Sinensis seed oil was done according to the Standard procedure as described by. ${ }^{14}$ All the chemicals used for this analysis were of analytical grade, unless stated otherwise.

Determination of mineral content: Minerals content was analyzed using spectrophotometric methods according to the Standard procedure as described by.$^{15}$ All the chemicals used for this analysis were of analytical grade, unless stated otherwise. Sample was analyzed for sodium $(\mathrm{Na})$, potassium $(\mathrm{K})$, calcium $(\mathrm{Ca})$, iron $(\mathrm{Fe})$, magnesium $(\mathrm{Mg})$, zinc $(\mathrm{Zn})$, copper $(\mathrm{Cu})$ and phosphorus $(\mathrm{P})$.

Determination of vitamins: The separation and detection of the vitamins were performed using atomic absorption spectrophotometer (AAS) according to the method described by. ${ }^{11,16}$ Sample was analyzed for vitamin A, D, E \& K.

Determination of fatty acid composition: Fatty acids contents were determined using gas chromatography/ mass spectrometry (GC-MS) Agilent technology $7890 \mathrm{GC}$ system and the model of the detector is Agilent technology 5975 MSD (Mass Spect. Detector). The column model is HP5 MS with length $30 \mathrm{~m}$, internal diameter $0.320 \mathrm{~mm}$, while the thickness was $0.25 \mu \mathrm{m}$. The oven temperature program was initial temperature of $80^{\circ} \mathrm{C}$ held for 1 minute. It increases by 100 per minute to the final temperature of $240^{\circ} \mathrm{C}$ to hold for 6 minutes. The injection volume was 1 microlitre and the heater or detector temperature is $250^{\circ} \mathrm{C}$. The citrus sinensis seed oil extracted was put in a vial bottle and the vial bottle was placed in the auto injector sample compartment. The automatic injector injected the sample into the liner. The mobile phase pushes the sample from the liner into the column where separation took place into different components at different retention time. The MS interpret the spectrum MZ (mass to charge ratio) with molar mass and structures as previously reported by. ${ }^{11}$

\section{Results}

\section{Anti-nutrient}

Table 1 revealed the Anti-nutrient composition of citrus sinensis seed oil. For each of the parameter; Phytate, Oxalate, Tannins, Alkaloids and Saponin were respectively assayed for in triplicate and the average value was reported. The anti-nutrients levels were found to be; Phytate $0.031 \pm 0.002$, Oxalate $3.980 \pm 0.011$, Tannins $2.681 \pm$ 0.014 , Alkaloids $0.018 \pm 0.001$ and Saponin $3.170 \pm 0.042$ respectively.

Table I Anti-nutrient composition of sweet orange Citrus sinensis seed oil

\begin{tabular}{ll}
\hline Parameters & Values \\
\hline Phytate $(\mathrm{mg} / \mathrm{l00g})$ & $0.03 \mathrm{I} \pm 0.002$ \\
Oxalate $(\%)$ & $3.980 \pm 0.0 \mathrm{II}$ \\
Tannins $(\mathrm{mg} / \mathrm{l00g})$ & $2.68 \mathrm{I} \pm 0.014$ \\
Alkaloids $(\mathrm{mg} / \mathrm{l00g})$ & $0.018 \pm 0.00 \mathrm{I}$ \\
Saponin $(\mathrm{mg} / \mathrm{l00g})$ & $3.170 \pm 0.042$ \\
\hline
\end{tabular}

Values are expressed as Mean \pm standard deviation, $n=3$.

\section{Vitamins and minerals}

The vitamin and mineral composition of citrus sinensis seed oil is revealed in Table 2 and Table 3. The result which is an average of the triplicate value of the vitamins and minerals present in citrus sinensis seed oil, showed that; the highest vitamin composition of citrus sinensis seed oil is Vitamin A $0.76 \pm 0.01$, followed by Vitamin K $0.032 \pm 0.002$, then Vitamin E $0.016 \pm 0.005$ and lowest Vitamin D $0.0084 \pm 0.0014$ (Table 2). The mineral content (Table 3) showed the presence of eight (8) minerals out of the nine (9) investigated for. The minerals that were found to be present are as follows: Calcium $(\mathrm{Ca})$

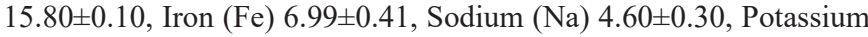
(K) 4.80 \pm 0.20 , Manganese $(\mathrm{Mn}) \quad 0.07 \pm 0.01$, Magnesium $(\mathrm{Mg})$ 6.22 \pm 0.22 , Zinc (Zn) 0.28 \pm 0.02 , and Phosphorus (P) 407.40 \pm 2.00 .

Table 2 Vitamin composition of sweet orange Citrus sinensis seed oil

\begin{tabular}{lll}
\hline Vitamins & Values $(\mathbf{m g})$ & DSID unit equivalent (IU \& $\boldsymbol{\mu g})$ \\
\hline Vitamin A & $0.76 \pm 0.01$ & $2533.33 \mathrm{IU}$ \\
Vitamin D & $0.0084 \pm 0.0014$ & $336 \mathrm{IU}$ \\
Vitamin E & $0.016 \pm 0.005$ & $23.88 \mathrm{IU}$ \\
Vitamin K & $0.032 \pm 0.002$ & $32 \mu \mathrm{g}$ \\
\hline
\end{tabular}

Values are expressed as Mean \pm standard deviation, $n=3$.

DSID denotes, dietary supplement ingredient database

Table 3 Mineral content of sweet orange citrus sinensis seed oil

\begin{tabular}{lll}
\hline Minerals & Values (mg/L) & $\begin{array}{l}\text { FDA (Recommended daily } \\
\text { limits) }(\mathbf{m g})\end{array}$ \\
\hline Calcium (Ca) & $15.80 \pm 0.10$ & 1000 \\
Iron (Fe) & $6.99 \pm 0.4 \mathrm{I}$ & 18 \\
Sodium (Na) & $4.60 \pm 0.30$ & 2400 \\
Potassium (K) & $4.80 \pm 0.20$ & 3500 \\
Manganese (Mn) & $0.07 \pm 0.01$ & 2 \\
Magnesium (Mg) & $6.22 \pm 0.22$ & 400 \\
Zinc $(\mathrm{Zn})$ & $0.28 \pm 0.02$ & 15
\end{tabular}


Table continued...

\begin{tabular}{lll}
\hline Minerals & Values (mg/L) & $\begin{array}{l}\text { FDA (Recommended daily } \\
\text { limits) }\end{array}$ \\
\hline Copper $(\mathrm{Cu})$ & $0.00 \pm 0.00$ & 2 \\
Phosphorus (P) & $407.40 \pm 2.00$ & 1000 \\
\hline
\end{tabular}

Values are expressed as Mean \pm standard deviation, $\mathrm{n}=3$.

\section{Proximate}

Investigation of the proximate composition of citrus sinensis seed oil was carried in triplicate for parameter assay and the average taken and presented in Table 4 . The result revealed the quantity of the proximate composition expressed in percentage as follows; Protein $1.560 \pm 0.120$, Moisture content $4.636 \pm 0.153$, Fat $89.810 \pm 0.282$, Ash content $1.776 \pm 0.161$, Crude fibre, $0.619 \pm 0.052$ and Carbohydrate $1.614 \pm 0.036$.

Table 4 Proximate analysis of citrus sinensis seed oil

\begin{tabular}{ll}
\hline Parameters & Content (\%) \\
\hline Protein & $1.560 \pm 0.120$ \\
Moisture content & $4.636 \pm 0.153$ \\
Fat & $89.810 \pm 0.282$ \\
Ash content & $1.776 \pm 0.161$ \\
Crude fibre & $0.619 \pm 0.052$ \\
Carbohydrate & $1.614 \pm 0.036$ \\
\hline
\end{tabular}

Values are expressed as Mean \pm standard deviation, $n=3$.

\section{Fatty acid}

The fatty acid composition of citrus sinensis seed oil was analyzed using Gas Chromatography-Mass Spectrometry. The result presented in Table 5 revealed the presence of some fatty acids, quantified and expressed in percentage (\%) as follows; Linoleic acid $37.644 \%$, Palmitic acid 28.051\%, Isopropyl linoleate $12.699 \%$, Pentadecanoic acid $9.652 \%$, Stearic acid $5.839 \%$, Butyl linoneate 2.867, Glutaric acid $2.616 \%$.

\section{Discussion}

Highlighting the nutritional benefit of oil gleaned from the seed of sweet orange Citrus sinensis has become very necessary; owing to the fact that, the seed is predominantly considered a waste. Therefore, the present study investigated some nutritional property of sweet orange Citrus sinensis seed oil. The anti-nutrient composition of the oil gleaned from the seed of sweet orange Citrus sinensis (Table 1) revealed that, phytate content was found to be $0.031 \pm 0.002 \%$, Tannin $2.681 \pm 0.014 \%$, Saponin $3.170 \pm 0.042 \%$, alkaloids $0.018 \pm$ $0.001 \%$ and Oxalate $3.980 \pm 0.011 \%$. Correspondingly, the levels of these anti-nutrients were found to be within the safe limits. the levels of tannins above $5 \%$ in the diet are often lethal, ${ }^{17}$ Phytates is recommended to be as low as possible within the range of $25 \mathrm{mg}$ or $0.035 \%$ in food to be beneficial to health, ${ }^{18,19}$ and Saponin at levels $<10 \%$ in a diet is said to be harmless to the body. ${ }^{20}$ Above the safe limits; the presence of oxalate in foods causes irritation in the mouth and interferes with absorption of divalent minerals particularly calcium by forming insoluble salts, ${ }^{20,21}$ and phenolic compounds, tannins, saponins, enzyme inhibitors, and cyanogenic glycosides have been shown to reduce the availability of certain nutrients and impair growth. ${ }^{22}$ The level of anti-nutrient (Tannin, Phytate, Saponin, Oxalate and Alkaloid) present in the sweet orange Citrus sinensis seed oil ranged within tolerable limit and cannot possibly prompt a toxic effect when used.

As previously reported by ${ }^{11}$ vitamins are essential component of food; deficiency in vitamin A and D causes blindness and rickets in children, vitamin $\mathrm{E}$ has antioxidant properties, vitamin $\mathrm{K}$ is required to minimize blood loss in case of injury deficiency and increases calcium deposition which could lead to coronary artery calcification and the development of heart disease. ${ }^{11,23,24}$ In this regard, of course, the seed oil of sweet orange Citrus sinensis in the present study (Table 2) revealed the presence of this essential component of food; Vitamin A, D, E and K respectively. Vitamin A content was found to be $0.76 \pm 0.01 \mathrm{mg}$, Vitamin D $0.0084 \pm 0.0014 \mathrm{mg}$, Vitamin E $0.016 \pm 0.005 \mathrm{mg}$ and Vitamin K $0.032 \pm 0.002 \mathrm{mg}$. According to the unit conversion of Dietary Supplement Ingredient Database, ${ }^{25}$ the equivalence of the vitamin contents level reported in Table 2 in the international unit (IU) and microgram $(\mu \mathrm{g})$ are as follows; Vitamin A: 2533.33IU, Vitamin D: 336UI, Vitamin E: 23.88UI and Vitamin $\mathrm{K}: 32 \mu \mathrm{g}$. Correspondingly, these values were found to fall within the recommended daily intake limits (5000UI, 400UI, 30UI and $80 \mathrm{mcg}$ respectively) by U.S Food and Drug Administration FDA. ${ }^{11}$ Additionally, Minerals are the macronutrient that are important for human nutrition and contribute to good health. The result of this study (Table 3) revealed that, sweet orange Citrus sinensis seed oil was found to contain $\mathrm{Ca}, \mathrm{Mg}, \mathrm{K}, \mathrm{Na}, \mathrm{P}, \mathrm{Mn}, \mathrm{Fe}$, and $\mathrm{Zn}$ (Table 3), and the value of the following macronutrients; $\mathrm{Mg}, \mathrm{K}, \mathrm{Na}, \mathrm{P}, \mathrm{Mn}$, $\mathrm{Fe}$, and $\mathrm{Zn}$ were all found not to exceed the recommended range for daily intake by the U.S (FDA). ${ }^{11}$ The seed oil was found to be a rich source of phosphorus with a concentration of $407.40 \pm 2.00 \mathrm{mg}$. This was found to be within the FDA daily recommended allowance of $1000.00 \mathrm{mg}$. Manganese is important in the transport of oxygen to the cells, useful in mental functions and as cofactors to enzymes responsible for fat, protein and carbohydrate metabolism. ${ }^{26}$ The mean value of $\mathrm{Mn}$ obtained in the seeds oil was $0.07 \pm 0.01 \mathrm{mg}$ which is within safe limits, not exceeding the daily intake recommendation of U.S (FDA) of $2 \mathrm{mg}$. Calcium is an important macronutrient needed for various physiological and biochemical processes in the body. ${ }^{11}$ The $\mathrm{Ca}$ content of the seed oil was found to be $15.80 \pm 0.10 \mathrm{mg}$ which is significantly lower than the FDA dietary allowance. Zinc is a wellknown antioxidant and a metallo-enzyme which plays vital roles in the reproductive, central nervous and immune systems. The mean values of $\mathrm{Zn}$ in the seed oil were $0.28 \pm 0.02 \mathrm{mg}$ which is within safe limits, not exceeding the daily intake recommendation of U.S (FDA) of $15 \mathrm{mg}$. Zinc deficiency is associated with dwarfism, respiratory infection, taste insensitivity, reduced growth and increased diarrhea in children. ${ }^{24}$ Magnesium $(\mathrm{Mg})$ is present in the center of the porphyrin in the molecule responsible for photosynthesis, the same as iron $(\mathrm{Fe})$ in the heam of heamoglobin. Iron $(\mathrm{Fe})$ is an important metal in the human body which is responsible for the red coloration of the blood and it is the center of the haem group in haemoglobin. The $\mathrm{Fe}$ content of the seed oil was found to be $6.99 \pm 0.10 \mathrm{mg}$ which is below the FDA recommended daily limits of $18.00 \mathrm{mg}$. The deficiency of iron leads to anemia. ${ }^{27}$ The presence of magnesium is associated with the release of parathyroid hormones in vital organs and tissues, oxidative phosphorylation, normal muscle contraction and relaxation and the conversion of vitamin $\mathrm{D}$ to its active form. The mean $\mathrm{Mg}$ content of the seed oil was $6.22 \pm 0.22 \mathrm{mg}$. This is significantly lower than the daily recommended intake of $\mathrm{Mg}$ by the U.S (FDA) which is $400 \mathrm{mg}$. Deficiency of $\mathrm{Mg}$ results in convulsion and calcium plays an important role in strengthening the tissues as well as bones of the body. ${ }^{28}$ The Na content in the seed oil was very low $(4.60 \pm 0.30 \mathrm{mg})$ compared to the FDA recommended daily limits (2400.00mg). Copper 
is a micronutrient required in very small quantities within the limits of $2.00 \mathrm{mg}$, however, copper was not detected.

Investigation of the proximate composition of sweet orange Citrus sinensis seed oil was carried out in triplicate for parameter assay and the average taken and presented in Table 4 . The result revealed the quantity of the proximate composition expressed in percentage as follows; Protein $1.560 \pm 0.120$, Moisture content $4.636 \pm 0.153$, Fat $89.810 \pm 0.282$, Ash content $1.776 \pm 0.161$, Crude fibre $0.619 \pm 0.052$ and Carbohydrate $1.614 \pm 0.036$. Comparable to similar findings, no report was found for the proximate composition of sweet orange Citrus sinensis seed oil, although related species of $C$. sinensis where reportedly higher in proximate composition; C. sinensis (Mussami) from Pakistan, ${ }^{29}$ and C. sinensis (Hamlin) from Brazil. ${ }^{5}$ However, the proximate content of $C$. sinensis seed oil notwithstanding the species variation continues to be excellent nutritional and beneficial seed oil, and also a source of quality edible oils. ${ }^{8}$

The fatty acid components present in sweet orange Citrus sinensis seed oil were identified by Gas Chromatography-Mass Spectrometry (GC-MS) analysis. The GC-MS chromatogram of 8 peaks of compounds detected is demonstrated in Figure 5. The retention time (RT), compound identified and concentrations (\% peak area) are presented in Table 5. sweet orange Citrus sinensis seed oil in the present study contains the following fatty acid compounds; Linoleic acid $37.644 \%$, Palmitic acid $28.051 \%$, Isopropyl linoleate $12.699 \%$, Pentadecanoic acid $9.652 \%$, Stearic acid 5.839\%, Butyl linoleates 2.867 , Glutaric acid $2.616 \%$. Each of this polyunsaturated fatty acid, monounsaturated fatty acid and phospholipids confers great nutritional and medicinal benefit. Our result is consistent with the findings of which reported that; from the standpoint of human nutrition, a major benefit to be derived from the consumption of citrus seed oils (and many other seed oils) in preference to animal fats it's in their high content of essential fatty acids particularly linoleic acid which falls within the range of 37.2-45.2\%. ${ }^{8}$ Clearly, the level of linoleic acid $(37.644 \%)$ present in the result of this study was found to fall within the reported range, and certainly makes this oil one of those high in polyunsaturated fatty acids. ${ }^{8}$ Additionally, the levels of Palmitic, Stearic and Linoleic fatty acid present in the sweet orange Citrus sinensis seed oil from Nigeria (Table 5) was almost similar to that of Iran $27.6 \%, 6.5 \%$ and $34 \%$ respectively, as reported by ${ }^{30}$ Therefore, indicating that, the oil extracted from sweet orange Citrus sinensis seeds regardless of the geographical location, has demonstrated to be an excellent source of essential fatty acids and point to be of high potential for both nutritional and industrial purposes.

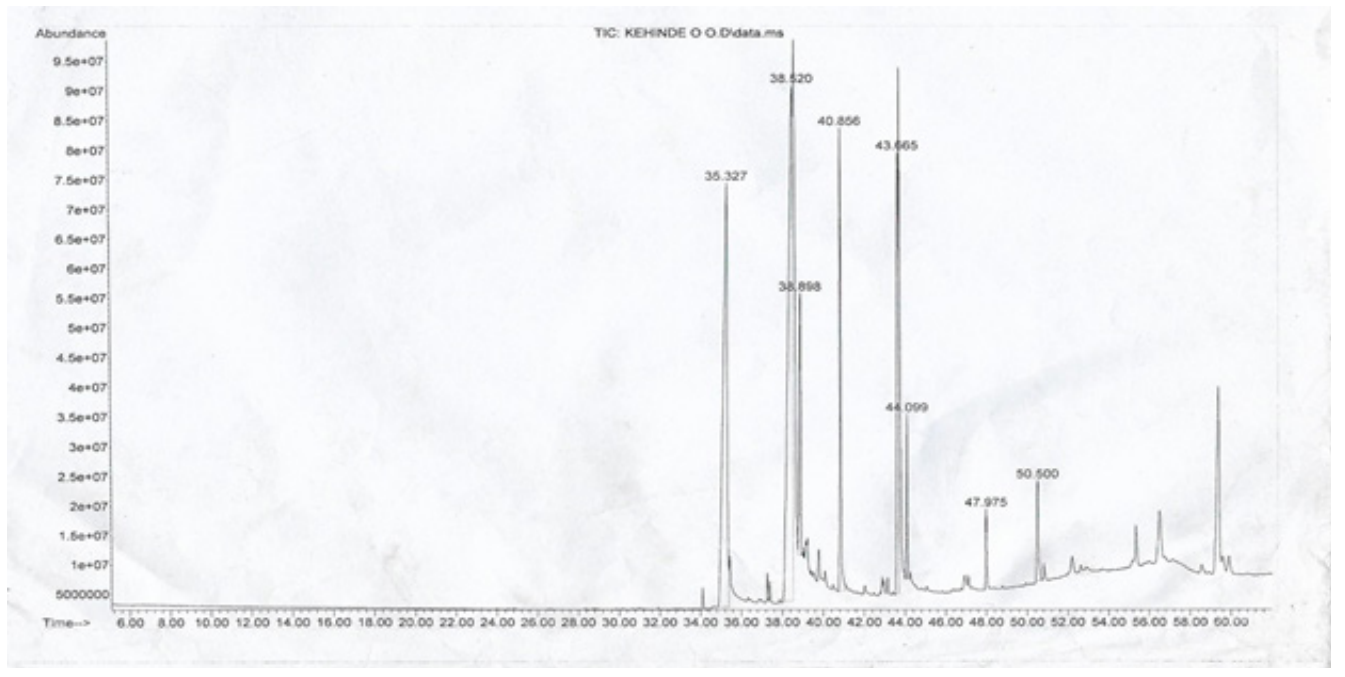

Figure 5 GC-MS Chromatogram of the oil of Citrus sinensis seed.

Table 5 fatty acid composition of citrus sinensis seed oil

\begin{tabular}{lll}
\hline Retention time (minutes) & Fatty acid & Content (\%) \\
\hline 38.52 & Linoleic acid $\left(\mathrm{C}_{18} \mathrm{H}_{32} \mathrm{O}_{2}\right)$ & 37.644 \\
35.327 & Palmitic acid $\left(\mathrm{C}_{16} \mathrm{H}_{32} \mathrm{O}_{2}\right)$ & 28.051 \\
43.665 & Isopropyl linoleate $\left(\mathrm{C}_{21} \mathrm{H}_{38} \mathrm{O}_{2}\right)$ & 12.699 \\
40.856 & $\mathrm{I}, 15-$ Pentadecanoic acid $\left(\mathrm{C}_{15} \mathrm{H}_{28} \mathrm{O}_{4}\right)$ & 9.652 \\
38.898 & Stearic acid $\left(\mathrm{C}_{18} \mathrm{H}_{36} \mathrm{O}_{2}\right)$ & 5.839 \\
50.5 & Butyl linoneate $\left(\mathrm{C}_{22} \mathrm{H}_{40} \mathrm{O}_{2}\right)$ & 2.867 \\
44.099 & Glutaric acid $\left(\mathrm{C}_{5} \mathrm{H}_{8} \mathrm{O}_{4}\right)$ & 2.616 \\
\hline
\end{tabular}

\section{Conclusion}

The result of the present study revealed that, sweet orange Citrus sinensis seed oil contains a low level of Anti-nutrient, contains reasonable amount of polyunsaturated fatty acids, and contains an excellent amount of vitamin and mineral within the recommended safe limits. Therefore, the benefit to be derived from the consumption and use of sweet orange Citrus sinensis seed oils in preference to animal fats cannot be overemphasized, so it is an excellent choice for both nutritional and industrial purposes. 


\section{Acknowledgments}

None.

\section{Funding}

None.

\section{Conflicts of interest}

The authors declare that there is no conflict of Interest.

\section{References}

1. Sowmya V, Kalekhan F, Kamath K, et al. Fruits in the prevention of cataractogenesis by targeting the aldose reductase. Foods and Dietary Supplements in the Prevention and Treatment of Disease in Older Adults. 2015:105-109.

2. Saonere S, Jyotsna A. An overview of Citrus aurantium used in treatment of various diseases. Afr J Plant Sci. 2011;5(7):390-395.

3. Etebu E, Nwauzoma AB. A review on sweet orange (Citrus sinensis Osbeck): health, diseases, and management. Am J Res Commun. 2014;2:33-70.

4. Sapna BS. Antimicrobial effects of Citrus sinensis peel extracts against dental caries bacteria: An in vitro study. J Clin Exp Dent. 2016;8(1):e71e77.

5. Aranha CP, Neuza J. Physico-chemical Characterization of Seed Oils Extracted from Oranges (Citrus sinensis). Food Sci Technol Res. 2013;19(3):409-415.

6. El-Desoukey RMA, Areej SB, Heelah FA. The phytochemical and antimicrobial effect of citrus sinensis (orange) peel powder extracts on some animal pathogens as eco-friendly. EC Microbiology. 2018;14(6):312-318.

7. Neuza J, Ana CDS, Caroline PM. Antioxidant activity of oils extracted from orange (Citrus sinensis) seeds. An Acad Bras Cienc. 2016;88(2):951-958.

8. Adeyeye EI, Adesina AJ. Citrus seeds oils as sources of quality edible oils. Int J Curr Microbiol App Sci. 2015;4(5):537-554.

9. Olabanji IO, Ajayi SO, Akinkunmi EO, et al. Physicochemical and in vitro antimicrobial activity of the oils and soap of the seed and peel of Citrus sinensis. Afr J Microbiol Res. 2016;10(8):245-253.

10. Maruf O, Yekeen O, Olayiwola OA, et al. Antifungal activities of Citrus sinensis seed oil against Lentinus sajor-caju. Adv Appl Sci Res. 2014;5(3):109-113.

11. Nwozo SO, Nwawuba SU. Physicochemical characteristics and nutritional benefits of Nigerian Cyperus esculentus (Tigernut) oil. Int $J$ Food Sci Nutr. 2018;3(4):212-216.

12. Njoku NE, Ubbaonu CN, Alagbaoso SO, et al. Proximate, antinutritional and phytochemical composition of the yellow variety of the synsepalum dulcificum (miracle fruit) berry. Am J Food Technol. 2016;4(4):102-108.
13. Auta SA, Kumurya AS. Comparative proximate, mineral elements and anti-nutrients composition between Musa sapientum (Banana) and Musa paradisiaca (Plantain) pulp flour. SJBR. 2015;4(4):025-030.

14. AOAC. Official methods of analysis. 18th Ed. Association of Official Analytical Chemists; 2005.

15. AOAC. Official methods of analysis of AOAC international. 16th Ed. Arlington, VA, USA: Association of Analytical Communities; 1995.

16. Ruales J, Nour BM. Content of fat, vitamins and minerals in quinoa grains. Food Chem. 1993;48:31-36.

17. Reed JD. Nutritional toxicology of tannins and related polyphenols in forage legumes. J Anim. Sci. 1995;73:1516-1528.

18. Abdoulaye C, Brou K, Jie C. Phytic acid in cereal grains: structure, healthy or harmful ways to reduce phytic acid in cereal grains and their effects on nutritional quality. Am J Plant Nutr Fertilization Tech. 2011;1:1-22.

19. Onomi S, Okazaki Y, Katayama T. Effect of dietary level of phytic acid on hepatic and serum lipid status in rats fed a high-sucrose diet. Biosci Biotechnol Biochem. 2004;68:1379-1381.

20. Unuofin JO, Otunola GA, Afolayan AJ. Essential oil Composition, nutrient and antinutrient analysis of vernonia mespilifolla, Less. Res $J$ Bot. 2017; 12:38-45.

21. Ladej O, Akin CU, Umaru HA. Level of anti-nutritional factors in vegetables commonly eaten in Nigeria. Afr J Nat Sci. 2004;7:71-73.

22. Shahidi F. Antinutrients and phytochemicals in food. ACS Symposium Series, Washington, DC: American Chemical Society; 1997:1-9.

23. Kebashni T, John M. The roles of vitamin D and dietary calcium in nutritional rickets. Bone Reports. 2018;8:81-89.

24. Hartley L, Clar C, Ghannam O, et al. Vitamin K for the primary prevention of cardiovascular disease. The Cochrane Database Syst Rev. 2015;9(9):CD011148.

25. Dietary Supplement Ingredient Database (DSID). A US Government Initiative by the office of dietary supplements and US department of agriculture. National Institute of Health Office of Dietary Supplements; 2019.

26. Feumba DR, Ashwini RP, Ragu SM. Chemical composition of some selected fruit peels. EJFST. 2016;4(4);12-21.

27. Edori OS, Marcus AC. Phytochemical screening and physiologic functions of metals in seed and peels of Citrullus Lanatus (Water melon). IJGHC. 2017;6(1):35-46.

28. Kouris-Blazos A, Belski R. Health benefits of legumes and pulses with a focus on Australian sweet lupins. Asia Pac J Clin Nutr. 2016;21(1):1-17.

29. Farooq A, Rehana N, Bhanger MI, et al. Physico-chemical characteristics of citrus seeds and seed oils from Pakistan. $\mathrm{J}$ Am Oil Chem Soc. 2008;85:321-330.

30. Mohammad R, Issa MP, Shahrokh N, et al. Physicochemical characteristics of citrus seed oils from Kerman Iran. J Lipids. 2014:1-3. 